\title{
INBREEDING DEPRESSION AND GENETIC VARIABILITY IN AGRICULTURAL TRAITS AND RESISTANCE TO PLANT PATHOGENS IN EXOTIC MAIZE POPULATIONS
}

\author{
DEPRESSÃO ENDOGÂMICA E VARIABILIDADE GENÉTICA EM CARACTERES \\ AGRONÔMICOS E DE RESISTENNCIA A FITOPATÓGENOS EM POPULAÇÕES \\ EXÓTICAS DE MILHO
}

\section{Aurilene Santos OLIVEIRA ${ }^{1}$; Edésio Fialho dos REIS ${ }^{3}$; Ana Paula Oliveira NOGUEIRA ${ }^{2}$; Fernando Cezar JULIATTI ${ }^{4}$}

1,4. UFU- Universidade Federal de Uberlândia, Instituto de Ciências Agrárias, Uberlândia, MG, Brasil. aurilene.s.oliveira@hotmail.com, juliatti@ufu.br; 2. Universidade Federal de Uberlândia, Instituto de Biotecnologia, Uberlândia, MG, Brasil; 3. UFJa- Universidade Federal de Jataí, Jataí, GO, Brasil; 4 Pesquisador 1 D pelo CNPq. Professor Titular da UFU

\begin{abstract}
The effect known as depression by inbreeding refers to the reduction on the average value of quantitative traits, related to plant reproduction and physiology, due to the homozygosis of deleterious alleles. This study evaluated the inbreeding depression and the genetic variability of agricultural traits and of the resistance to phytopathogens in inbred families of two exotic maize populations. The experiments were done in the experimental area of the Universidade Federal de Goiás, Regional Jataí, in the second harvest 2015. Fifty and $40 \mathrm{FS}_{1}$ of NAP5 and NAP7 populations, respectively, were evaluated interplanting one row with a mixture of base population (family of Germanic siblings) at every ten plots to estimate depression by inbreeding of the traits evaluated. The experimental design was randomized blocks, with three replications. The following traits were evaluated: $\mathrm{PH}-$ plant height $(\mathrm{cm}), \mathrm{EH}-$ ear height $(\mathrm{cm}), \mathrm{MF}$ - male flowering (days), BP - number of broken plants, LP - number of lodged plants, KW - kernel weigh $\left(\mathrm{kg} \mathrm{plot}^{-1}\right)$, ET resistance to Exserohilum turcicum, WS(White Spot) - resistance to Pantoea ananatis, CS(Corn Stunt) - resistance to the corn stunt, PP - resistance to Puccinia polysora and CZ - resistance to Cercospora zea-maydis. The greatest estimates of depression by inbreeding in the agricultural traits were observed for kernel production, with values of 51.2 and $38.9 \%$ for the populations NAP5 and NAP7, respectively. Among the traits of resistance to phytopathogens, the greatest estimate was observed for the stunting complex, with values of $-58.9 \%$ in NAP5 and $-74.2 \%$ in NAP7. Both populations under study presented genetic potential to be used in breeding programs with recurrent selection and, after some selection cycles, lineages with good agricultural standard and resistance to phytopathogens can be obtained.
\end{abstract}

KEYWORDS: Leaf diseases. Endogamic families. Genetic parameters. Zea mays.

\section{INTRODUCTION}

Endogamy is defined as a phenomenon that occurs due to mating between related individuals (CRUZ, 2005). Oftentimes endogamy is undesirable in Hardy-Weinberg equilibrium populations, such as maize, because this type of crossing leads to homozygosis and, in these populations, there are recessive deleterious genes that, in homozygosis, cause harm to plant physiology, decreasing its phenotypic value (MIRANDA FILHO, 2001).

The genetic causes controlling inbreeding depression are not completely known; however, there are some hypotheses to explain them. One of these hypotheses is that favorable genes tend to be dominant or partially dominant; another hypothesis states that the heterozygote has greater phenotypic value than the homozygote (CROW; KIMURA, 1970). Inbreeding depression, in the former, is the rupture of the ideal combination of alleles that control the character under study.

Self-fertilization is the driving mechanism of endogamy, since it allows that common alleles by ancestry be found in the same individual, presenting great importance to obtain lineages. The value of a population as lineage source is highly dependent on inbreeding depression in relation to several characteristics, limiting the potential of obtaining vigorous lineages for subsequent production of hybrids (HALLAUER et al., 2010). In order to obtain lineages with acceptable probability, a breeding program should start with populations with high frequency of favorable alleles of important 
Inbreeding depression...

traits, while presenting low frequency of undesirable alleles (VENCOVSKY; BARRIGA, 1992). Consequently, when an improved population is subjected to self-fertilization, few deleterious alleles are expressed for a given quantitative trait, resulting in lower estimates by inbreeding depression along the selection cycles, in comparison to the original, non-improved populations.

A study with three semi-exotic maize populations demonstrated that population CRE-01, obtained from a crossing of exotic lineages with a commercial hybrid that had passed through selections to eliminate deleterious genes, presented less inbreeding depression for the traits evaluated in relation to two other populations (OLIVEIRA et al., 2015).

The use of endogamic progenies can be a good strategy for traits that present low heritability, since inbreeding makes available greater genetic variability due to the crossing system, which allows obtaining estimates for the favorable genetic parameters in the selection process. In the breeding perspective, endogamy can be potentially used for the development of lineages with alleles of interest which, subsequently, will be used in the composition of simple, double or triple maize hybrids, or even in recurrent selection involving partially endogamic progenies $\left(S_{1}, S_{2}\right.$ and $\left.S_{3}\right)$, for the development of improved populations (HALLAUER et al., 2010).

Besides improving desirable agricultural traits, the search for sources of resistance to plant pathogens has been one of the main foci of maize breeding programs. Presently, diseases constitute one of the main yield limiting factors and the primary control method is the use of resistant genotypes. However, the search of greater yielding and uniform genotypes resulted in a narrowing of the genetic basis, increasing vulnerability to biotic and abiotic stresses (COTA et al., 2015).

The exotic germplasm can be used both to obtain genotypes with superior agronomic traits and as a source of resistance to diseases of importance for the corn culture, promoting an increase in the genetic variability of this cereal. However, its use in maize breeding programs around the world has been inexpressive (GOODMAN, 2005). The potential of exotic or semi-exotic populations in maize breeding programs has been reported by several authors (OLIVEIRA et al., 2015; MENDES et al., 2015; SILVA et al., 2017; SOUZA et al., 2018). Juliatti et al 2004, 2009 and 2013 showed the possibilities of selection to plant pathogens resistance at endogamic population in maize to main diseases (cercospora leaf spot, common rust and white spot).
OLIVEIRA, A. S. et al.

This study evaluated inbreeding depression and the genetic potential of agricultural traits and the resistance against plant pathogens (Exserohilum turcicum Leonard and Suggs, Pantoea ananatis (White Spot), phytoplasm, spiroplasm, Puccinia polysora and (Cercospora Leaf Blight) Cercospora zeae Tehon and Daniels) in endogamic families of two exotic maize populations.

\section{MATERIAL AND METHODS}

The experiments were done from February to July 2015 (second harvest) in Jataí/GO, at the experimental area of Universidade Federal de Goiás, at $17^{\circ} 52^{\prime} 53^{\prime \prime}$ and $51^{\circ} 42^{\prime} 52^{\prime \prime} \mathrm{W}, 676 \mathrm{~m}$ above sea level.

Maize populations NAP5 (resistant to Exerohilum turcicum) and NAP7 (resistant to Physopella zeae) originated from a technicalscientific cooperation Project NAP-Maize (Nucleus of Support to Maize Research), created by the Department of Genetics at ESALQ/USP (Escola Superior de Agricultura "Luiz de Queiroz"/ Universidade de São Paulo) to identify reliable sources of resistance to the major maize leaf diseases. Several public institutions (CNPMS/EMBRAPA, IAC - Instituto Agronômico de Campinas, IAPAR - Instituto Agronômico do Paraná, ESALQ-USP, CENARGEM/EMBRAPA) and private enterprises (empresas Zêneca Sementes, Sementes Colorado, FT Sementes, Sementes Agroceres) joined the program.

One thousand two hundred and seventy three accesses of the BAG (Active Germplasm Bank, CENARGEM/EMBRAPA) were evaluated in the agricultural year 1994/1995 in thirteen locations in the states of Goiás, Mato Grosso, São Paulo and Paraná. Visual evaluations for resistance to five leaf diseases were done, with exclusive selection for each phytopathogens, excluding some accesses with low standards of yield and plant architecture. The number of accesses that entered in the composition of each population were 41 (NAP5) and 34 (NAP7). Each population was formed by an isonumeric seed sample of each selected access.

Endogamic families in each population were obtained by sowing two fields for crossings, each one consisting of 500 seeds. Fifty and 40 endogamic families $\left(\mathrm{FS}_{1}\right)$ were obtained from selfpollination of populations NAP5 and NAP7, respectively, for the experiments in Jataí-GO. The experimental design was randomized blocks, with three replications. Each experimental plot consisted of one 2-m long row, and rows were 0.9 meters apart from each other. Plots had 10 plants after thinning. Three plants in the center of the plot were 
used to evaluate disease severity for each pathogen. Disease severity evaluations started when the first symptoms appeared, and three evaluations were done with 14 days interval between them.

White spot and helminthosporiosis severity evaluations were done with specific diagrammatic scales (MALAGI et al., 2011; LAZAROTO et al., 2012). Severity of cercosporiosis, polisora rust and the corn stunt were done with the scale developed by Agroceres (1996), used to evaluate most maize leave diseases.

One plot of the base population of each population was inserted at every ten $\mathrm{FS}_{1}$ plots. An internal border was used to avoid the effect of the competitive effect of the base population with the endogamic lineages, in such a way that for each plot of the base population planted, two rows of that same population were used for protection, and externally to these two rows, two other rows were inserted as borders with a mixture of endogamic lineages. Agricultural management of both experiments was done according to the recommendations for maize (FANCELLI; DOURADO-NETO, 2000).

The characters plant height $(\mathrm{PH})$, ear height (EH), male flowering (MF), number broken plants (BP), number lodged plants (LP), kernel weight (KW), number of plants (NP), resistance to Exserohilum turcicum (HT), resistance to Pantoea
OLIVEIRA, A. S. et al.

ananatis (WS), resistance to corn stunt (CS), resistance to Puccinia polysora (PR) and resistance to Cercospora zeae-maydis (CZ) were evaluated. However, the number of plants was used only to make a correction on kernel weight to the ideal number of plants (10 plants), using the correction by covariance method, suggested by Miranda Filho (VENCOVSKY; BARRIGA, 1992).

The analyses and estimates of statisticalgenetic parameters were done with the Program Genes (CRUZ, 2016).

\section{RESULTS AND DISCUSSION}

Population NAP7 presented greater averages for most variables of the agricultural traits evaluated (Table 1) than population NAP5, except for BP, which was similar for both populations. The observed averages of $\mathrm{PH}$ and $\mathrm{KW}$ for both exotic populations were considered low. Consequences of inbreeding are reduction in plant height and ear size and, consequently, in yield (BORÉM; MIRANDA, 2017). The values of KW were 2.01 and $2.09 \mathrm{t} \mathrm{ha}^{-1}$ for populations NAP5 and NAP7, respectively. Although the averages of KW for both populations were low, $\mathrm{S}_{1}$ families with yield greater than four tons were observed, indicating the productive potential of these populations for recurrent selection programs.

Table 1. Averages of base population $\left(\mathrm{m}_{0}\right)$, averages of endogamic families $\left(\mathrm{m}_{1}\right)$, estimates of depression by endogamy (DP\%), contribution of homozygotes $\left(\mu+\mathrm{a}^{*}\right)$ and of heterozygotes $\left(\mathrm{d}^{*}\right)$ and experimental coefficient of variation $(\mathrm{CV} \%)$ for six agronomic traits in two exotic maize populations. Jataí, 2015

\begin{tabular}{|c|c|c|c|c|c|c|}
\hline & \multicolumn{6}{|c|}{${ }^{£}$ Traits } \\
\hline Estimates & $\mathrm{PH}$ & EH & MF & $\mathrm{BP}$ & LP & KW \\
\hline & \multicolumn{6}{|c|}{ Population NAP5 } \\
\hline $\mathrm{m}_{0}$ & 187.4 & 104.3 & 59 & 2 & 3 & 4.12 \\
\hline $\mathrm{m}_{1}$ & 162.7 & 92.7 & 61 & 1 & 3 & 2.01 \\
\hline $\mathrm{DP}_{\%}$ & 13.2 & 11.1 & -3.4 & 50.0 & 0 & 51.2 \\
\hline$\left(\mu+a^{*}\right)$ & 138.0 & 81.1 & 63 & 0 & 3 & -0.10 \\
\hline $\mathrm{d}^{*}$ & 49.4 & 23.2 & -4 & 2 & 0 & 4.22 \\
\hline \multirow[t]{2}{*}{$\mathrm{CV} \%$} & 11.0 & 14.7 & 1.8 & 79.1 & 51.3 & 28.1 \\
\hline & \multicolumn{6}{|c|}{ Population NAP7 } \\
\hline $\mathrm{m}_{0}$ & 204.1 & 107.1 & 60 & 1 & 6 & 3.42 \\
\hline $\mathrm{m}_{1}$ & 182.2 & 96.2 & 62 & 1 & 5 & 2.09 \\
\hline $\mathrm{DP}_{\%}$ & 10.7 & 10.2 & -3.3 & 0 & 16.7 & 38.9 \\
\hline$\left(\mu+a^{*}\right)$ & 160.3 & 85.3 & 64 & 1 & 3 & 0.76 \\
\hline $\mathrm{d}^{*}$ & 43.8 & 21.8 & -4 & 0 & 0 & 2.66 \\
\hline CV \% & 10.1 & 13.2 & 1.9 & 108.8 & 41.1 & 24.3 \\
\hline
\end{tabular}

${ }^{£}$ Traits - PH: plant height (cm); EH: ear height (cm); MF: flowering male (dias); BP: number of broken plants; LP: number of lodged plants; KW: kernel weight $\left(\mathrm{t} \mathrm{ha}^{-1}\right)$; 
Inbreeding depression...

The observed averages of $\mathrm{PH}, \mathrm{EH}$ and $\mathrm{KW}$ of both populations evaluated were lower than those observed in other studies with inbred exotic and semi-exotic maize populations (RODRIGUES, 2013; OLIVEIRA et al., 2015).

The population NAP5 presented the lowest averages of AUDPC (Table 2) for all five diseases
OLIVEIRA, A. S. et al.

evaluated, indicating greater resistance than NAP7. Some $S_{1}$ families of the two populations presented high resistance to $\mathrm{HT}, \mathrm{WS}, \mathrm{CS}, \mathrm{PR}$ and $\mathrm{CZ}$. This result demonstrates the potential of the exotic populations for use as resistance sources to phytopathogens in maize breeding programs.

Table 2. Averages of base population $\left(\mathrm{m}_{0}\right)$, averages of endogamic families $\left(\mathrm{m}_{1}\right)$, estimates of depression by endogamy (DP\%), contribution of homozygotes $\left(\mu+\mathrm{a}^{*}\right)$ and of heterozygotes $\left(\mathrm{d}^{*}\right)$ and experimental coefficient of variation (CV\%) for area under the disease progress curve (AUDPC) of five diseases in two exotic maize populations. Jataí, 2015

\begin{tabular}{|c|c|c|c|c|c|}
\hline \multirow{3}{*}{ Estimates } & \multicolumn{5}{|c|}{${ }^{£}$ Diseases (AUDPC) } \\
\hline & ET & WS & $\mathrm{CS}$ & PR & $\mathrm{CZ}$ \\
\hline & \multicolumn{5}{|c|}{ Population NAP5 } \\
\hline $\mathrm{m}_{0}$ & 277.8 & 309.1 & 567.9 & 280.8 & 175.8 \\
\hline $\mathrm{m}_{1}$ & 396.8 & 292.6 & 902.1 & 255.9 & 201.1 \\
\hline $\mathrm{DP}_{\%}$ & -42.8 & 5.3 & -58.9 & 8.9 & -14.4 \\
\hline$\left(\mu+a^{*}\right)$ & 515.8 & 276.1 & 1236.3 & 231.0 & 226.4 \\
\hline $\mathrm{d}^{*}$ & -238.0 & 33.0 & -668.4 & 49.8 & -50.6 \\
\hline \multirow[t]{2}{*}{$\mathrm{CV} \%$} & 35.7 & 32.6 & 37.6 & 35.3 & 40.6 \\
\hline & \multicolumn{5}{|c|}{ Population NAP7 } \\
\hline $\mathrm{m}_{0}$ & 398.1 & 380.4 & 594.2 & 329.0 & 183.3 \\
\hline $\mathrm{m}_{1}$ & 471.7 & 302.8 & 1034.8 & 309.6 & 223.1 \\
\hline $\mathrm{DP}_{\%}$ & -18.5 & 20.4 & -74.2 & 5.9 & -21.7 \\
\hline$\left(\mu+a^{*}\right)$ & 545.3 & 225.2 & 1475.4 & 290.2 & 262.9 \\
\hline$d^{*}$ & -147.2 & 155.2 & -881.2 & 38.8 & -79.6 \\
\hline CV\% & 31.8 & 31.5 & 28.1 & 38.6 & 40.9 \\
\hline
\end{tabular}

According to the classification for experimental coefficients of variation for maize, proposed by Scapim et al. (1995), the trials presented values indicating good experimental precision for most of the traits evaluated, except for estimated values of BP, LP and the resistance to diseases, which had values above $28.1 \%$. These results are due to strong environment effect on these traits, which cannot be controlled. Thus, high coefficients of variation for these traits are accepted and do not compromise the experimental precision. Brito et al. (2011), studying resistance of maize hybrids to cercospora leaf spot (Gray Leaf Spot) and white spot, found coefficient of variation values of 37.0 and $48.2 \%$ for these diseases, respectively.

The population NAP5 presented greater estimates of depression by inbreeding (DP\%) for most agricultural traits evaluated than population NAP7, except for the trait LP. The DP\% estimates for both populations, for the traits $\mathrm{PH}, \mathrm{EH}, \mathrm{MF}$ and AC were low, highlighting that the effects of dominance are less important for them. Bernini et al. (2013), in studies of inbred families, obtained for self-pollination of hybrids, reported low DP\% values for $\mathrm{PH}, \mathrm{EH}$ and $\mathrm{MF}$.

Both populations presented high estimate of $\mathrm{DP} \%$ for the trait $\mathrm{KW}$, indicating that both of them are sensitive to inbreeding for this trait. Therefore, new cycles of recurrent selection are required for both populations in order to reduce their genetic load and, from the selection of superior genotypes, obtain lineages with excellent agricultural standards. High values of $\mathrm{DP} \%$ for $\mathrm{KW}$ in exotic and semiexotic maize populations were observed by Rodrigues (2013) and Oliveira et al. (2015). Good and Hallauer (1977) confirmed that production is strongly affected by inbreeding at any degree of homozygosis. 
Inbreeding depression...

The relative contribution of heterozygotes $\left(d^{*}\right)$ was greater than that of homozygotes to BP in the population NAP5. This result implies, indirectly, the existence of genetic heterogeneity in the populations. Taking into account the genetic effects, the estimates of depression by inbreeding are smaller for $\mathrm{PH}$ and $\mathrm{EH}$ than for the trait kernel production because the effects of gene dominance are less important for these traits (LIMA et al., 1984). High values of contribution by homozygotes $\left(\mu+a^{*}\right)$ are indicative of the potential of the populations as sources of lineages with high productive potential. The contribution of loci in homozygosis for the traits $\mathrm{PH}, \mathrm{EH}, \mathrm{MF}$ and $\mathrm{PH}$ was greater than that of the loci in heterozygosis.

The estimates of $\mu+\mathrm{a}^{*}$ for $\mathrm{KW}$ in both populations are low; thus, in order to effectively extract lineages from them, it is necessary to select the best endogamic families and recombine them for new evaluations, in such a way that the populations will concentrate greater number of favorable alleles, allowing the retrieval of lineages with good productive potential. Maldonado and Miranda Filho (2002) presented similar results to those observed in this study for kernel production.

Increased severity of the diseases HT, CS and $\mathrm{CZ}$ were observed after one generation of selfpollination, indicating a negative effect of inbreeding, making both exotic populations more sensitive to these three diseases. The estimates of DP\% varied from -58.9 to 8.9 for NAP5 and from 74.2 to 20.4 for NAP7. The AUDPC of CS was variable and presented the greatest $\mathrm{DP} \%$ in both populations evaluated. The effect of inbreeding for WS and PP reduced severity, conferring greater resistance to these phytopathogens. Values of DP\% between 14.6 and 26.8 for CS were observed by Oliveira et al. (2015) in three semi-exotic maize populations selected as resistance source to the pathogens of the corn stunt disease.

The contribution of loci in homozygosis (additive effects) was greater than those in heterozygosis (deviations due to dominance) for the reduction of disease severity of WS and PP in both populations, while for the diseases $\mathrm{HT}, \mathrm{CS}$ and $\mathrm{CZ}$, the contribution of loci in heterozygosis was more expressive in the reaction of resistance to these phytopathogens. Therefore, endogamic families in both populations were more resistant to WS and PP than the base population, while the base population was more resistant to the phytopathogens HT, CS and $\mathrm{CZ}$ due to the greater contribution of the loci in heterozygosis in relation to those in homozygosis for these.
OLIVEIRA, A. S. et al.

Success in selective process depends on the existence of genetic variability for agricultural traits and resistance to phytopathogens in the breeding programs with focus on genetic resistance to diseases. Based on the results of the analyses of variance of the traits evaluated in both maize populations (Tables 3 and 4), significant differences were observed among $\mathrm{S}_{1}$ families for all traits evaluated, except for CS in population NAP5 and for $\mathrm{BP}, \mathrm{LP}$ and $\mathrm{CZ}$ in NAP7, which were not significant. Consequently, there is genetic variability for the agricultural traits and the expression of resistance to the diseases evaluated in both exotic maize populations, with the possibility of obtaining gains through genetic breeding and, thus, producing better adapted and resistant maize populations for the production of lineages.

Although the results of the analysis of variance are important as indicators of the potential of a given population and of the experimental precision, it still is insufficient for the breeder because it does not provide the magnitude of the available genotypic variability (CRUZ et al., 2014). Therefore, estimating genetic variance along with other components becomes indispensable for the studies of genetic breeding.

Population NAP5 presented greater genetic variability for the traits $\mathrm{PH}, \mathrm{EH}, \mathrm{BP}, \mathrm{LP}$, WS and $\mathrm{CZ}$ (Tables 5 and 6) than NAP7, while the later presented greater estimates for the traits $\mathrm{MF}, \mathrm{KW}$, HT and CS than the former. Population NAP7 presents greater genetic potential for the trait $\mathrm{KW}$ since, although average yield of both populations is similar, NAP7 presented greater genetic variability than NAP5 and genetic gains are more promising in populations with greater variability. The selection of families more resistant to $\mathrm{CZ}$ is more promising in population NAP5; however, the same selection in NAP7 for this trait will be ineffective since this population does not present genetic variability to promote genetic gains. Similarly, population NAP5 did not present genetic variability for CS, making the population NAP7 more adequate for the selection of more resistant families.

Studies of endogamic families in four exotic maize populations reported values of genetic variance for $\mathrm{PH}$ between 88.69 and 326.01 and for EH between 90.82 and 112.53 (RODRIGUES, 2013). Oliveira et al. (2015) reported estimates of genetic variance for $\mathrm{KW}$ in endogamic families of three semi-exotic families between 190.2 and 227.5.

The estimates of broad sense heritability coefficient for the agricultural traits of family averages were equal to or greater than 0.7 for $\mathrm{PH}$, $\mathrm{EH}, \mathrm{MF}$ and $\mathrm{KW}$ in population NAP5 and for $\mathrm{EH}$, MF and KW in NAP7. Heritability estimates equal 
Inbreeding depression...

to or greater than 0.7 favor the selection process with greater genetic gains. Heritability estimates for traits related to resistance to phytopathogens were between 0.55(PP-NAP7) and 0.85 (WS-NAP5). Such heritability magnitude indicate that the major
OLIVEIRA, A. S. et al.

variability cause presented by the populations was due to genetic effects, and acceptable genetic gains can be obtained with the selective process of progenies that are more resistant to these pathogens.

Table 3. Mean squares of the analysis of variance of agronomic traits in endogamic families $\left(\mathrm{FS}_{1}\right)$ of two exotic maize populations. Jataí (GO), 2015

\begin{tabular}{|c|c|c|c|c|c|c|c|}
\hline Source & ${ }^{(1)}$ d.f. & ${ }^{£,(2)} \mathrm{PH}$ & ${ }^{£,(2)} \mathrm{EH}$ & ${ }^{\mathfrak{E}} \mathrm{MF}$ & ${ }^{£} \mathrm{BP}$ & ${ }^{£} \mathrm{LP}$ & ${ }^{£,(2)} \mathrm{KW}$ \\
\hline \multicolumn{8}{|c|}{ Population NAP-5 } \\
\hline Replication & 2 & 19.448 & 10.790 & 0.050 & 0.010 & 0.124 & 0.490 \\
\hline Progenies & 49 & $11.934 * *$ & $7.531 * *$ & $0.041 * *$ & $0.028 * *$ & $0.043 *$ & $3.453 * *$ \\
\hline Error & 98 & 3.184 & 1.856 & 0.012 & 0.011 & 0.027 & 1.039 \\
\hline \multicolumn{8}{|c|}{ Population NAP-7 } \\
\hline Replication & 2 & 38.039 & 10.232 & 0.001 & 0.014 & 0.068 & 0.253 \\
\hline Progenies & 39 & $9.995 * *$ & $5.897 * *$ & $0.156 * *$ & $0.017^{\mathrm{NS}}$ & $0.053^{\mathrm{NS}}$ & $6.807 * *$ \\
\hline Error & 78 & 3.370 & 1.611 & 0.014 & 0.011 & 0.041 & 0.833 \\
\hline
\end{tabular}

${ }^{£}$ : PH: plant height (cm); EH: ear height (cm); MF: male flowering (days); BP: broken plants; LP: lodged plants; KW: kernel weight $\left(\mathrm{g} \mathrm{plant}^{-1}\right)$ corrected for number of plants; ${ }^{(1)}$ : degrees of freedom; ${ }^{(2)}$ : variance values divided by $10^{2} ;^{* * *,}$ NS: significant at $1 \%, 5 \%$ and not significant by F-test, respectively.

Table 4. Mean squares of the analysis of variance of resistance to phytopathogens in $\mathrm{S}_{1}$ families in two exotic maize populations. Jataí, 2015

\begin{tabular}{|c|c|c|c|c|c|c|}
\hline Source & ${ }^{(1)}$ d.f. & ${ }^{£,(2) \mathrm{E}} \mathrm{ET}$ & ${ }^{£,(2)} \mathrm{WS}$ & f,(2) $\mathrm{CS}$ & f,(2) $\mathrm{PP}$ & f,(2) $\mathrm{CZ}$ \\
\hline \multicolumn{7}{|c|}{ Population NAP-5 } \\
\hline Replication & 2 & 51.734 & 27.965 & 318.808 & 4.427 & 28.062 \\
\hline Progenies & 49 & $62.219 * *$ & $59.985 * *$ & $168.165^{\mathrm{NS}}$ & $25.549 * *$ & $17.085^{* *}$ \\
\hline Error & 98 & 20.109 & 9.090 & 114.949 & 8.151 & 6.670 \\
\hline \multicolumn{7}{|c|}{ Population NAP-7 } \\
\hline Replication & 2 & 226.352 & 3.196 & 247.603 & 73.527 & 4.286 \\
\hline Progenies & 39 & $105.734 * *$ & $49.939 * *$ & $226.589 * *$ & $31.741 * *$ & $12.014^{\mathrm{NS}}$ \\
\hline Error & 78 & 22.502 & 9.120 & 84.437 & 14.246 & 8.341 \\
\hline
\end{tabular}

Table 5. Estimates of genotypic variance $\left(\boldsymbol{\sigma}_{G}^{2}\right)$, of heritability based on Family averages $\left(\boldsymbol{h}_{m}^{2}\right)$, of the coefficient of genetic variation $\left(\mathrm{CVg}_{0}\right)$ and of the variation index $(\theta)$ for six agronomic traits of $\mathrm{S}_{1}$ families of two exotic maize populations. Jataí, 2015

\begin{tabular}{lllllll}
\hline \multicolumn{5}{c}{ Traits } & \multicolumn{1}{l}{} \\
\hline Estimates & PH & EH & MF & BP & LP & KW \\
\hline \multirow{2}{*}{$\sigma_{\mathrm{G}}^{2}$} & Population NAP5 & & & & & \\
$h_{\mathrm{m}}^{2}$ & 291.69 & 189.15 & 0.94 & 0.66 & 0.52 & 80.47 \\
$\mathrm{CV}$ & 0.73 & 0.75 & 0.70 & 0.64 & 0.36 & 0.70 \\
$\Theta$ & 10.50 & 14.84 & 1.60 & 60.51 & 22.39 & 24.77 \\
& 0.96 & 1.01 & 0.87 & 0.77 & 0.44 & 0.88 \\
$\sigma_{\mathrm{g}}^{2}$ & Population NAP7 & & & & - & 199.10 \\
$h_{\mathrm{m}}^{2}$ & 220.85 & 142.88 & 4.74 & - & - & 0.88 \\
$\mathrm{CV}$ & 0.66 & 0.73 & 0.91 & - & - & 37.46 \\
$\Theta$ & 8.16 & 12.43 & 3.54 & - & - & 1.55 \\
\hline
\end{tabular}

${ }^{\mathfrak{t}}$ Traits - AP: plant height (cm); AE: ear height (cm); FM: tasseling (days); PQ: number of broken plants; AC: number of lodged plants; PG: kernel weight $\left(\mathrm{g}\right.$ plant $\left.{ }^{-1}\right)$; 
Table 6. Estimates of genotypic variance $\left(\boldsymbol{\sigma}_{G}^{2}\right)$, heritability based on family average $\left(\boldsymbol{h}_{m}^{2}\right)$, of the genetic variation coefficient $(\mathrm{CVg} \%)$ and of the variation index $(\theta)$ for resistance to phytopathogens in $S_{1}$ families of two exotic maize populations. Jataí, 2015.

\begin{tabular}{|c|c|c|c|c|c|}
\hline \multirow{3}{*}{ Estimates } & \multicolumn{5}{|c|}{${ }^{£}$ Diseases (AUDPC) } \\
\hline & ${ }^{(1) \mathrm{E}} \mathrm{ET}$ & ${ }^{(1)} \mathrm{WS}$ & ${ }^{(1)} \mathrm{CS}$ & ${ }^{(1)} \mathrm{PP}$ & ${ }^{(1)} \mathrm{CZ}$ \\
\hline & \multicolumn{5}{|c|}{ Population NAP5 } \\
\hline$\sigma_{\mathrm{G}}^{2}$ & 14.037 & 16.965 & - & 5.799 & 3.472 \\
\hline$h_{\mathrm{m}}^{2}$ & 0.68 & 0.85 & - & 0.68 & 0.61 \\
\hline $\mathrm{CV}_{\mathrm{g}} \%$ & 29.86 & 44.51 & - & 29.76 & 29.30 \\
\hline \multirow[t]{2}{*}{$\Theta$} & 0.84 & 1.37 & - & 0.84 & 0.72 \\
\hline & \multicolumn{5}{|c|}{ Population NAP7 } \\
\hline$\sigma_{\mathrm{G}}^{2}$ & 27.744 & 13.606 & 47.384 & 5.832 & - \\
\hline$h_{\mathrm{m}}^{2}$ & 0.79 & 0.82 & 0.63 & 0.55 & - \\
\hline $\mathrm{CV}_{\mathrm{g}} \%$ & 35.31 & 38.53 & 21.04 & 24.67 & - \\
\hline 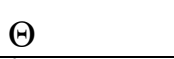 & 1.11 & 1.22 & 0.75 & 0.64 & - \\
\hline
\end{tabular}

The observed values of heritability coefficient for the traits $\mathrm{PH}$ and $\mathrm{EH}$ in this study were similar to those found by Oliveira et al. (2015) in endogamic families of semi-exotic maize populations. Population NAP5 presented lower values of KW than those observed by Rodrigues (2013) while population NAP7 presented similar values to those found by the same author in $S_{1}$ families of exotic maize populations.

The relation between $\mathrm{CVg}$ and $\mathrm{CVe}$ (index $\theta$ ), represents one more information for the breeder in relation to progeny selection (VENCOVSKY, 1987). As an example, Vencovsky and Barriga (1992), suggest that values of this index above 1.0 indicate a favorable condition for selection of progenies of half-siblings.

Population NAP5 presented indices above 1 for the traits EH and WS. The traits MF, KW, HT and WS from population NAP7 also presented indices above 1. Such results indicate favorable condition for the selection of progenies with desirable agricultural traits and selection of sources of resistance to these diseases.

Despite the comparisons of the indices of this study with those reported by Vencovsky and Barriga (1992), it is important to highlight that the present study evaluated $\mathrm{S}_{1}$ families and that genetic variance among these families tend to greater than that of half-sibling families, affecting the index of variation.

It is possible to obtain populations with short cycle, good kernel yield and presenting resistance to the main phytopathogens of maiz from the selection of superior progenies from the populations studies, since these presented excellent genetic potential to be exploited in recurrent selection programs.

\section{CONCLUSIONS}

The exotic populations presented high depression by endogamy, and it was not possible to use them to extract lineages before doing cycles of recurrent selection.

Both exotic populations presented genetic potential to be explored in breeding programs with recurrent selection, to obtain superior genotypes and resistant to main maize plant pathogens (Exserohilum turcicum, WS(White Spot) resistance to Pantoea ananatis, CS(Corn Stunt) resistance to the corn stunt, PP - resistance to Puccinia polysora and CZ(gray leaf spot) resistance to Cercospora zea-maydis.).

\section{ACKNOWLEDGMENTS}

The first author acknowledges CAPES for the doctorate scholarship, to the Universidade Federal de Uberlândia and to the Universidade Federal de Goiás/Campus Jataí for opportunity to develop the study, and to Prof. Dr. José Branco de Miranda Filho (in memoriam) for the scientific contributions to this study. 
RESUMO: O efeito denominado depressão por endogamia refere-se à redução do valor médio dos caracteres quantitativos, relacionados com a reprodução e a fisiologia da planta, devido ao estado de homozigose dos alelos deletérios. O objetivo deste trabalho foi avaliar a depressão por endogamia e a variabilidade genética de caracteres agronômicos e de resistência a fitopatógenos em famílias endogâmicas de duas populações exóticas de milho. Os experimentos foram realizados na área experimental da Universidade Federal de Goiás, Regional Jataí, na safrinha 2015. Foram avaliadas 50 e $40 \mathrm{FS}_{1}$ das populações NAP5 e NAP7, respectivamente, intercalando a cada dez parcelas uma linha com a mistura da população base (família de irmãos germanos) para estimar a depressão por endogamia dos caracteres avaliados. Os experimentos foram instalados em delineamento de blocos casualizados, com três repetições. Foram avaliados os seguintes caracteres: PH - altura de planta $(\mathrm{cm}), \mathrm{EH}$ - altura de espiga $(\mathrm{cm}), \mathrm{MF}$ - florescimento masculino (dias), BP número de plantas quebradas, LP - número de plantas acamadas, $\mathrm{KW}$ - produção de grãos $\left(\mathrm{kg}\right.$ parcela $\left.{ }^{-1}\right)$, ET resistência a Exserohilum turcicum, WS (White Spot) - resistência a Pantoea ananatis, CS (Corn Stunt) - resistência ao complexo de enfezamento, PP - resistência a Puccinia polysora e CZ resistência a Cercospora zea-maydis. As maiores estimativas de depressão por endogamia nos caracteres agronômicos foram observadas para produção de grãos, com valores de 51,2 e 38,9\% para as populações NAP5 e NAP7, respectivamente. Nos caracteres de resistência a fitopatógenos, a maior estimativa foi observada para o complexo de enfezamento, com valores de $-58,9 \%$ na NAP5 e $-74,2 \%$ na NAP7. As duas populações em estudo apresentaram potencial genético para serem utilizadas em programas de melhoramento com seleção recorrente e após alguns ciclos de seleção extrair linhagens com bom padrão agronômico e resistentes a fitopatógenos.

PALAVRAS-CHAVE: Doenças foliares. Famílias endogâmicas. Parâmetros genéticos, Zea mays.

\section{REFERENCES}

AGROCERES. Guia agroceres de sanidade. São Paulo: Sementes Agroceres. 1996, 72p.

BERNINI, C. S.; PATERNIANI, M. E. A. Z.; DUARTE, A. P. GALLO, P. B.; GUIMARÃES, P. S.; ROVARIS, J. R. S. Depressão endogâmica e heterose de híbridos de populações F2 de milho no estado de São Paulo. Bragantia, Campinas, v. 72, n. 3, p. 217-223, 2013. https://doi.org/10.1590/brag.2013.038

BORÉM, A.; MIRANDA, G.V. Melhoramento de plantas. 6.ed. Viçosa: UFV, 2013. 523p.

BRITO, A. H.; VON PINHO, R. G.; SANTOS, A. O.; SANTOS, S. Reação de híbridos de milho e comparação de métodos para avaliação da Cercosporiose e Mancha Branca. Tropical Plant Pathology, v. 36, n. 1, p. 35-41, 2011. https://doi.org/10.1590/S1982-56762011000100005

COTA, L. V.; COSTA, R. V.; SILVA, D. D. Manejo de doenças. In: BORÉM, A.; GALVÃO, J. C. C.; PIMENTEL, M. A. Milho: do plantio à colheita. 1.ed. Viçosa: UFV, 2015. Cap. 13, p. 294-322.

CROW, J. F.; KIMURA, M. An introduction to population genetics theory. Minneapolis: Alpha Editions, 1970, 591p.

CRUZ, C. D. Princípios de Genética Quantitativa. $1^{\text {a }}$ Ed., Viçosa: Ed. UFV, v. 1, 2005. 394p.

CRUZ, C. D.; CARNEIRO, P. C. S.; REGAZZI, A. J. Modelos biométricos aplicados ao melhoramento genético. Viçosa: Imprensa Universitária, v. 2, 2014, 668p.

CRUZ, C. D. Genes Software extended and integrated with the R, Matlab and Selegen. Acta Scientiarum Agronomy, Maringá, v. 38, n. 4, p. 547-552, 2016. https://doi.org/10.4025/actasciagron.v38i3.32629

FANCELLI, A. L.; DOURADO NETO, D. Produção de Milho. Guaíba: Agropecuária, 2000. 360p. 
Inbreeding depression...

OLIVEIRA, A. S. et al.

GOOD, R. L.; HALLAUER, A. R. Inbreeding depression in maize by selfing an full-sibling. Crop Science, Madison, v. 17, p.935-940, 1977. https://doi.org/10.2135/cropsci1977.0011183X001700060030x

GOODMAN, M. M. Broadening the U.S. maize germplasm base. Maydica, v. 50, p. 203-214, 2005. HALLAUER, A. R.; CARENA, M.J.; MIRANDA FILHO, J. B. Quantitative genetics in maize breeding. New York: Springer, 2010.663p. https://doi.org/10.1007/978-1-4419-0766-0_12.

JULIATTI, F.C., PEDROSA, M.G., JULIATTTI, B.C.M., BELOTI, I.F., FIGUEIRO, A.A. Identificação de QTLs associados à resistência parcial à mancha branca do milho. Bioscience Journal., Uberlândia, v. 29, n. 5, p. $1163-1178$, Sept./Oct. 2013.

JULIATTI, F. C.; APPELT, C. C. N. S.; BRITO, C. H.; GOMES, L. S.; BRANDÃO, A. M.; HAMAWAKI, O. T.; MELO, B. Controle da feosféria, ferrugem comum e cercosporiose pelo uso da resistência genética, fungicidas e épocas de aplicação na cultura do milho. Bioscence Journal, Uberlândia, v. 20, n. 3, p. 45-54, 2004.

JULIATTI, F. C., PEDROSA, M.G., SILVA, H.D.,SILVA, J.V.C. Genetic mapping for resistance to gray leaf spot in maize. Euphytica, Wagening, p.1-12. April 2009. https:// doi 10.1007/s10681-009-9943-2.

LAZAROTO, A.; DOS SANTOS, I.; KONFLANZ, V. A.; MALAGI, G.; CAMOCHENA, R. C. Escala diagramática para avaliação de severidade da helmintosporiose comum em milho. Ciência Rural, Santa Maria, v. 42, n. 12, p. 2131-2137, 2012. https://doi.org/10.1590/S0103-84782012005000112

LIMA, M.; MIRANDA FILHO J. B.; BOLLER G. P. Inbreeding depression in Brazilian populations of maize (Zea mays L.). Maydica: v. 29, n. 3, p. 203-215, 1984.

MALAGI, G.; SANTOS, I.; CAMOCHENA, R. C.; MOCCELLIN, R. Elaboração e validação da escala diagramática para avaliação da mancha branca do milho. Revista Ciência Agronômica, v. 42, n. 3, p. 797-804, 2011. https://doi.org/10.1590/S1806-66902011000300028

MALDONADO, F. A. A.; MIRANDA FILHO, J.B. Inbreeding depression in maize populations of reduced size. Scientia agrícola, Piracicaba, v.59, n.2, p.335-340, 2002. https://doi.org/10.1590/S010390162002000200020

MENDES, U. C.; MIRANDA FILHO, J. B.; OLIVEIRA, A. S.; REIS, E. F. Heterosis and combining ability in crosses between two groups of open-pollinated maize populations. Crop Breeding and Applied

Biotechnology, v.15, p. 235-243, 2015. https://doi.org/10.1590/1984-70332015v15n4a40

MIRANDA FILHO, J. B. Endogamia ou consanguinidade. In: NASS, L. L.; VALOIS, A. C. C.; MELO I. S.; VALADARES-INGLIS, M. C. Recursos Genéticos \& Melhoramento. Fundação MT, Rondonópolis. 2001. p.629-647.

OLIVEIRA, A. S.; MIRANDA FILHO, J. B.; REIS, E. F. Variability and inbreeding in semiexotic maize populations. Genetics and Molecular Research, v. 14, n. 1, p. 1184-1199, 2015.

https://doi.org/10.4238/2015.February.6.21

OLIVEIRA, A. S.; REIS, E. F.; MIRANDA FILHO, J. B.; MENDES, U. C. RODRIGUES, L. O. Genetic variability and yield potential of three semiexotic maize ( Zea mays L.) populations variabilidade genética e potencial produtivo em três populações semiexóticas de milho (Zea mays L .). Bioscience Journal, v.31, n. 6, p. 1609-1617, 2015. https://doi.org/10.14393/BJ-v31n6a2015-28783

RODRIGUES, L.O. Variabilidade genética em quatro populações semiexóticas de milho. 2013. 57p. Dissertação (Mestrado em Agronomia - Produção Vegetal) - Universidade Federal de Goiás, Campus - Jataí, Jataí, 2013. 
SCAPIM, C. A.; CARVALHO, C. G. P.; CRUZ, C. D. Uma proposta de classificação dos coeficientes de variação para a cultura do milho. Pesquisa Agropecuária Brasileira, Brasília, v. 30, n.5, p. 683-686, 1995.

SILVA, C. M.; MIRANDA FILHO, J. B.; MENDES, U. C.; REIS, E. F. Partial diallel crosses for predicting yield of semiexotic maize populations. Genetics and Molecular Research, v. 16, n. 1, p. 1-16, 2017. https://doi.org/10.4238/gmr16019544

SOUZA, A. C.; MIRANDA FILHO, J. B. OLIVEIRA, A. S.; PINTO, J. F. N.; SILVA, C. M.; REIS, E. F. Genetic variability and expected gain in three maize populations. Revista Brasileira de Milho e Sorgo, v. 17, n.1, p. 135-146, 2018. https://doi.org/10.18512/1980-6477/rbms.v17n1p135-146

VENCOVSKY, R. Herança quantitativa. In: PATERNIANI, E.; VIÉGAS, G. P. Melhoramento e produção de milho. 2.ed. Campinas: Fundação Cargil, 1987. p. 137-214.

VENCOVSKY, R.; BARRIGA, P. Genética biométrica no fitomelhoramento. Ribeirão Preto: Sociedade Brasileira de genética, 1992, 496p. 